\title{
Autonomic neuropathy in diabetes mellitus
}

\author{
Alberto Verrotti ${ }^{1}$, Giovanni Prezioso ${ }^{2}$, Raffaella Scattoni ${ }^{1}$ and Francesco Chiarelli ${ }^{2}$ * \\ 1 Department of Pediatrics, University of Perugia, Perugia, Italy \\ ${ }^{2}$ Department of Pediatrics, University of Chieti, Chieti, Italy
}

Edited by:

Aaron Vinik, Eastern Virginia Medical

School, USA

\section{Reviewed by:}

Carmine Grieco, Glenville State

College, USA

Trevor S. Ferguson, The University of

the West Indies, Jamaica

${ }^{*}$ Correspondence:

Francesco Chiarelli, Department of Pediatrics, University of Chieti, Via dei Vestini 5, Chieti 66013, Italy

e-mail: chiarelli@unich.it

Diabetic autonomic neuropathy (DAN) is a serious and common complication of diabetes, often overlooked and misdiagnosed. It is a systemic-wide disorder that may be asymptomatic in the early stages. The most studied and clinically important form of DAN is cardiovascular autonomic neuropathy defined as the impairment of autonomic control of the cardiovascular system in patients with diabetes after exclusion of other causes. The reported prevalence of DAN varies widely depending on inconsistent definition, different diagnostic method, different patient cohorts studied. The pathogenesis is still unclear and probably multifactorial. Once DAN becomes clinically evident, no form of therapy has been identified, which can effectively stop or reverse it. Prevention strategies are based on strict glycemic control with intensive insulin treatment, multifactorial intervention, and lifestyle modification including control of hypertension, dyslipidemia, stop smoking, weight loss, and adequate physical exercise. The present review summarizes the latest knowledge regarding clinical presentation, epidemiology, pathogenesis, and management of DAN, with some mention to childhood and adolescent population.

Keywords: diabetic autonomic neuropathy, diabetes mellitus, autonomic nervous system, hyperglycemia, oxidative stress, advanced glycation end-products, inflammation, cardiovascular autonomic neuropathy

\section{DEFINITION}

Diabetic neuropathy is the main cause of neuropathy in the world (1). As one of the major complications (2), it plays a key role in morbidity and mortality in patients with type 1 and type 2 diabetes mellitus (T1DM and T2DM).

Diabetic neuropathy is classically defined as "the presence of symptoms and/or signs of peripheral nerve dysfunction in people with diabetes after the exclusion of other causes" (3). Sensory, motor, or autonomic nerves can be involved, often coexisting.

The Thomas and Boulton classifications distinguish between generalized symmetric polyneuropathies (DPNs) and focal/ multifocal neuropathies $(4,5)$.

Diabetic autonomic neuropathy (DAN) is included in the first group. Erroneously considered for a long time in the past century as a rare event, DAN is indeed a serious and often underestimated complication of diabetes for two main reasons: by potentially affecting any circuit/tract of autonomic nervous system, DAN is a systemic-wide disorder, which encompasses a large spectrum of organs and leads to significant increase in morbidity and mortality (6-8); moreover DAN in early stages may be asymptomatic, especially in young T1DM patients, often compromising early diagnosis and treatment.

In fact, subclinical DAN can occur within a year of diagnosis in T2DM and within 2 years in T1DM, while first symptoms may onset after years $(6,9,10)$.

\section{CARDIOVASCULAR AUTONOMIC NEUROPATHY}

The most common and studied manifestation of DAN is cardiovascular autonomic neuropathy (CAN), owing to its life-threatening complications (arrhythmias, silent myocardial ischemia, and sudden death) and to its relation with other microangiopathic comorbidities. CAN is defined as the impairment of autonomic control of the cardiovascular system (5). In recent years, much attention has been directed to early warning signs of CAN, detectable in the first years after diabetes onset by means of validated cardiovascular reflex tests (11) supported by newer procedures (12-14). Such warning signs include reduced heart rate (HR) variability during deep breath, prolongation of QT interval, temporally followed by resting tachycardia, impaired exercise tolerance, and decreased baroreflex sensitivity with consequent abnormal blood pressure regulation, and orthostatic hypotension $(12,15)$.

A recent cross-sectional study on 387 diabetic adult patients showed that there was a tendency toward increased CAN prevalence with increased resting HR and highlighted the importance of resting HR as a predictive value for CAN (16). Despite the evidence of the increase in CAN severity with diabetes duration, a study on 684 T1DM adult patients has recently reported that diabetes duration by itself was not a good predictor of CAN severity (17).

Cardiac alterations initially start with a relative increase of the sympathetic tone, since diabetic neuropathy firstly affects longest fibers as those of parasympathetic system (like the vagus nerve). Sympathetic denervation begins at the following stage, by affecting the heart from the apex toward the base, gradually impairing ventricle function and resulting in cardiomyopathy (12).

\section{OTHER MANIFESTATIONS OF DAN}

The central control of breathing and the sympathetic bronchial innervation can also be jeopardized by the autonomic impairment. Both peripheral and central chemosensitivity to hypoxia is altered, as is the bronchomotor tone in lung. The coexistence 
of this finding with other risk factors like lung microvascular complications, endocrine impairments, obesity, and hypertension, lead to a higher prevalence of sleep apnea syndrome (SAS) in diabetic patient $(18,19)$. Clinical implications of SAS go from a decrease in quality of life due to sleepiness to an increased risk of sudden death (20). The meta-analysis of Fujihara et al. indicated that patients with DAN had about twofold higher prevalence of SAS than patients without DAN, the association being more remarkable among young patients with T2DM (21).

Furthermore, DAN may manifest with gastrointestinal (GI) symptoms, as a result of the remodeling of the enteric nervous system (ENS) induced by diabetes (22). Loss in inhibitory and increase in excitatory enteric neurons, as well as decrease in sensory neuropeptides, may induce gastroparesis, esophageal dysmotility, constipation, diarrhea, fecal incontinence, or gallbladder atony. In general, the presence of gastroparesis weakly correlates with upper GI autonomic symptoms (nausea, vomiting, early satiety, postprandial fullness, bloating, and abdominal pain), which are very common in T1DM and T2DM patients. Nevertheless, it has been reported (23) that gastric dysmotility has an impact in acute glycemic control by delaying glucose absorption while, on the other hand, acute glycemic imbalance may lead to temporary functional GI abnormalities.

The earlier damages to the sacral parasympathetic fibers contributes to genitourinary dysfunction, starting from impaired bladder sensation with increase in urine retention to dysuria, nicturia, incomplete bladder emptying, and urgency up to overflow incontinence due to the progressive involvement of motor sympathetic and somatic nerves $(5,7)$. Bladder dysfunction as well predisposes to recurrent urinary tract infections and may be predictive for long-term development of renal failure.

Diabetic autonomic neuropathy along with vasculopathy, connective tissue damage, and other psychological, endocrine, nutritional, and pharmacological factors may influence sexuality, by inducing erectile dysfunction, retrograde ejaculation and decreased sexual desire in female, dyspareunia, or inadequate lubrication (24-26).

Autonomic pupillomotor function and sudomotor function are not spared by DAN. The sympathetic predominance in pupil control decreases its diameter at rest (27). Preserved pupil miotic reaction to accommodation-convergence without the miotic reaction to light is named "Argyll-Robertson pupil," a clinical sign shared with neurosyphilis. Sweat gland denervation results in skin dryness, which is strongly linked to the development of typical foot ulcerations (28).

\section{EPIDEMIOLOGY}

The reported prevalence of DAN varies widely depending on different criteria used to define autonomic dysfunction, different type and number of tests performed, the use of age-related normative values, the presence or absence of signs and symptoms of autonomic neuropathy, and different patient cohorts studied $(5,14$, 29-33).

A meta-analysis of adult patients including 15 studies from 1966 to 2001 reported prevalence rates of CAN between 1 and $90 \%(30,34)$, while Dimitropoulos reported a prevalence of CAN that varies between 1 and 90\% in patients with T1DM and 20-70\% in patients with T2DM (14).

On the other hand, in a community-based population study, the prevalence of autonomic neuropathy, defined by one or more abnormal HR variability test results was $16.7 \%(34,35)$.

In 1992, Ziegler et al. in a multicenter study reported that the prevalence of CAN in T1DM and T2DM patients was 25.3 and $34.3 \%$, respectively (more than two of six abnormal autonomic function tests). Using more strict criteria (abnormalities in at least three of six autonomic function tests), the prevalence of CAN was $16.8 \%$ for patients with type 1 and $22.1 \%$ for individual with $\operatorname{T} 2 \operatorname{DM}(30,36)$ and a similar prevalence rate had been found by O'Brien et al. in patients with T1DM $(30,37)$.

In our experience (38), 47 of 110 diabetic children and adolescents showed one or more abnormal test for cardiovascular autonomic dysfunction, while in a prospective study, Solders et al. reported low sensory nerve conduction and autonomic dysfunction in about $25 \%$ of 144 diabetic children (39), instead Karavanaki found evidence of reduced papillary adaptation in darkness in $13.8 \%$ of children with diabetes compared with $5.8 \%$ of controls, $50 \%$ of these children also had impaired HR variation (40).

The Diabetes Control and Complications Trial (DCCT) found that $1.65 \%$ had abnormal HR variability at baseline in patients with $<5$ years duration of diabetes. The prevalence increased to $6.2 \%$ in patients with more than 5 but $<9$ years duration of diabetes and to $12.2 \%$ by 9 years duration of diabetes $(30,41)$.

The prevalence of confirmed CAN (defined as the abnormality of at least two cardiovascular HR results) in clinical studies in unselected populations, including both T1DM and T2DM patients, varies from 16.6 to $20 \%(31,42,43)$, and this prevalence may increase to $65 \%$ with increasing age and diabetes duration $(29,31)$. In particular, the prevalence may increase up to $38 \%$ in T1DM and $44 \%$ in T2DM patients aged $40-70$ years and up to $35 \%$ in T1DM and $65 \%$ in $\mathrm{T} 2 \mathrm{DM}$ patients with long standing diabetes $(31,33$, 44, 45).

Cardiovascular autonomic neuropathy is detected in about 7\% of both T1DM and T2DM at the time of diagnosis. The annual increase in prevalence of CAN has been reported about $6 \%$ in T2DM and 2\% in T1DM $(14,31,33,45,46)$.

Diabetic autonomic neuropathy may also cause GI disturbances, affecting every part of the GI tract: delayed esophageal transit $(50 \%)$, gastroparesis $(40 \%)$, disordered small and large intestinal motility with diarrhea (20\%) and constipation (25\%) $(5,30)$.

The prevalence of organic sexual dysfunction is also high with erectile dysfunction (35-90\%) and retrograde ejaculation (32\%) $(5,30)$.

Bladder dysfunction is detected in $43-85 \%$ of patients with T1DM and in $25 \%$ of T2DM $(5,30)$.

Discussing about pediatric population, a systematic review by Tang including 19 studies about young people with T1DM, reported a prevalence of DAN that varied between 16 and $75 \%$ for cardiovascular nerve function tests and between 8 and $16 \%$ in pupillometry studies (27). Furthermore, several studies reported a significant association between glycemic control, longer diabetes duration, and autonomic test abnormalities in young people (27). Only few studies analyze the association between DAN and 
other microvascular complications in young people with diabetes: retinopathy and nephropathy seems to be associated with DAN data from adult population (27).

\section{PATHOGENESIS}

\section{HYPERGLYCEMIA AND OXIDATIVE STRESS}

An increasing body of data supports the multifactorial genesis of DAN (Figure 1).

It is well established that hyperglycemia is the main driver of diabetic complications. The increase in blood and cytoplasmic glucose induces several metabolic pathways into a vicious cycle resulting in chronic tissue damage. Within the cell, the mitochondrial overproduction of reactive oxygen and nitrogen species (RONS) like superoxide anion radical, peroxynitrite, and hydrogen peroxide is the key event secondary to glucose overload (47). Longitudinal studies showed an higher prevalence of oxidative stress in female and an increased risk for sensory dysfunction, CAN, and mortality $(48,49)$. RONS in turn, induce DNA damage and consequently overstimulate the poly-ADP ribose polymerase (PARP), a repair enzyme inducing NAD consumption and decreasing glyceraldehyde 3-phosphatedehydrogenase (GAPDH) activity, already impaired by RONS. This results in endothelial

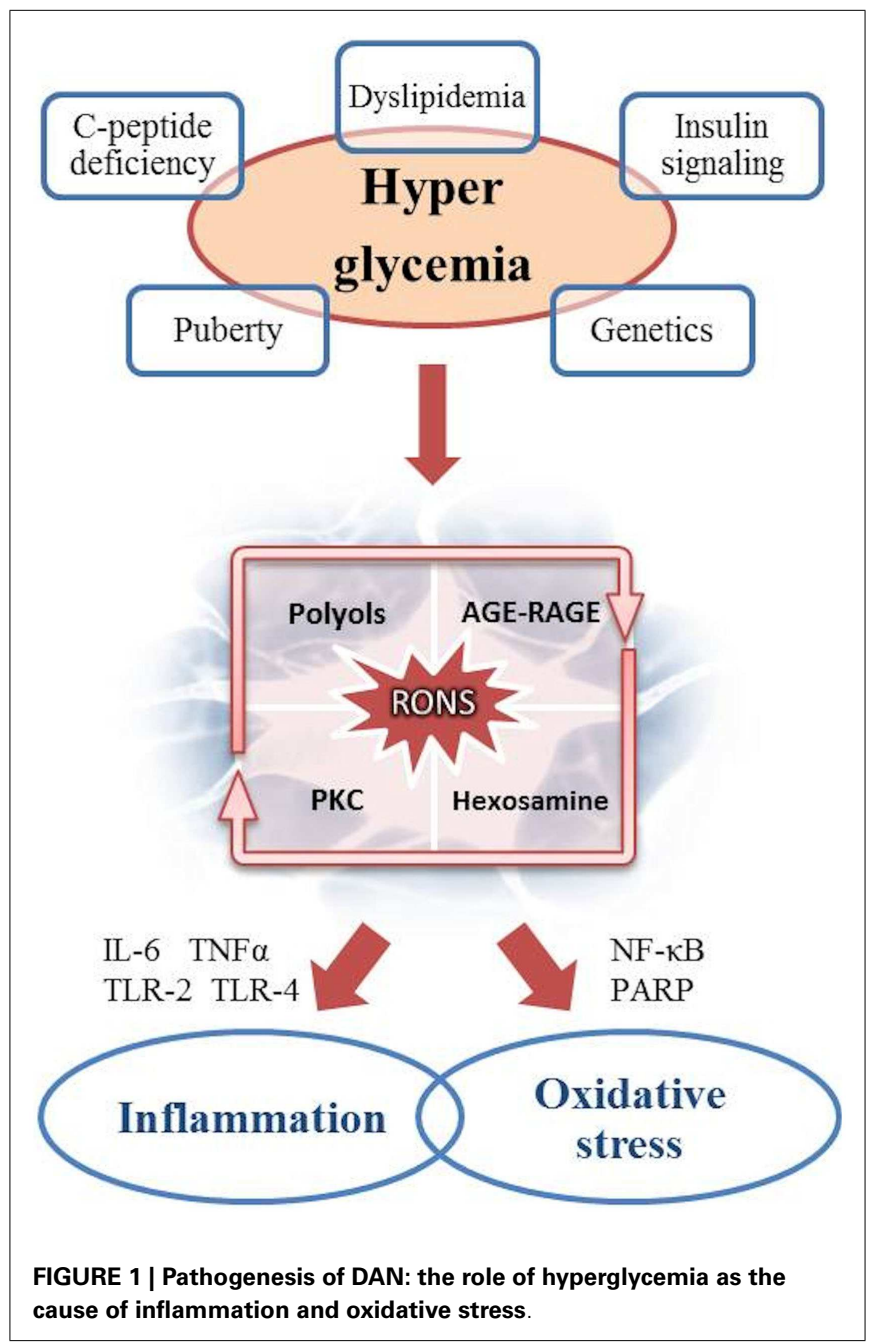

dysregulation and pro-apoptotic signals initiation, like advanced glycation end products (AGEs) formations. The production of AGEs leads to structural and functional protein alteration both in the extracellular matrix and in the intracellular space. AGEs may also interact with specific receptors (RAGEs), which create a complex pro-inflammatory cascade (involving IL-1, IL-6, TNF- $\alpha$, TGF- $\beta$, and VCAM- 1 ) and increase oxidative stress (14, 47, 48, 50, 51). It is noteworthy that experimental studies on RAGE knockout mice have demonstrated a reduced frequency in neuronal complications (52).

Protein kinase $\mathrm{C}(\mathrm{PKC})$ and hexosamine pathways are thus enhanced by the impaired cellular milieu, respectively, resulting in further production of RONS by means of NADPH oxidase complex, and in transcription of vascular impairment factors, like PAI- 1 , TGF- $\alpha$, and TGF- $\beta$ (50).

Furthermore, glucose in excess is converted into polyols, particularly sorbitol, whose increased flux consumes NADPH, involved in antioxidant regeneration. Polyols accumulation also inhibits $\mathrm{Na}^{+} / \mathrm{K}^{+}$ATPase, thus interacting with PKC pathway.

\section{INFLAMMATION}

The role of inflammation in the pathogenesis of DAN has increasingly been highlighted. Adhesion molecules expression, cytokine overproduction, phagocytic cells infiltration, and innate immune system activation via toll-like receptors (TLR-2 and TLR-4) cause secondary neuronal and vascular damage, also by determining a continuous cross-talk with the oxidative stress $(53,54)$. An increase in traditional circulating inflammatory markers like C-reactive protein (CRP), IL-6, IL-8, TNF- $\alpha$, and endothelin-1, as well as novel markers like the urokinase plasminogen activator receptor (SuPAR), have repeatedly been detected in several studies on T1DM and T2DM (55-61). These markers have been considered predictive for diabetic complications, especially CAN (62).

\section{OTHER FACTORS}

With reference to T1DM, the role of autoimmunity has also been considered. Autoantibodies against sympathetic ganglia, vagus nerve, and adrenal medulla were found in T1D patients $(63,64)$. Recent studies have shown that these antibodies were independent from islet autoimmunity while the data about the predictivity for future development of DAN and CAN are conflicting $(65,66)$.

Microvascular damage itself should not be underestimated as an indirect factor of neuronal dysfunction and apoptosis $(14,67)$. Even an impaired dynamic cerebral autoregulation has been linked to CAN (68).

Over the past decade, new pathogenic theories closely interrelated to the classic mechanisms have been suggested. A genetic predisposition to oxidative stress and an increased risk in neuropathy due to polymorphism of antioxidant enzymes like superoxide dismutase (SOD), glutathione peroxidase (GPX), and catalase (CAT) has been demonstrated in a diabetic population (69).

Great interest has been generated by the role of nerve growth factors in the pathogenesis of DAN: for instance, insulin-like growth factor-1 (IGF-1) and neurotrophin-3 (NT-3) have been demonstrated to reverse experimental diabetic neuropathy (70).

Besides the hyperglycemia, of particular interest are the studies on dyslipidemia showing the free fatty acids being key mediators of 
inflammation and oxidative damage, as well as elevation in plasma triglycerides or decrease in HDL cholesterol correlating to diabetic neuropathy $(67,71)$. Furthermore, in experimental studies, leptin receptor deletion in mice resulted in autonomic neuropathy (72).

Puberty can also have a certain pathogenetic importance (14, $73,74)$ : it appears to decrease insulin sensitivity, especially by rising $\mathrm{GH}$ and reducing IGF-1 circulating levels. This may alter the metabolic profile to promote microvascular complications $(32,75,76)$. Moreover, a poor compliance to therapy and diet should not be underestimated during adolescence in consequence of neuropsychological problems.

\section{PREVENTION}

Intensive glycemic control seems to be the most effective way to prevent/delay the onset and slow the progression of autonomic dysfunction in patients with T1DM $(14,30,33,46,77)$. The DCCT demonstrated that intensive glycemic treatment reduces the onset and the progression of diabetic complications (retinopathy, nephropathy, and neuropathy) and also reduces the rate of CAN by $53 \%$ compared to conventional therapy $(41,45,78$ 79). The Epidemiology of Diabetes Intervention and Complication (EDIC) study has demonstrated persistent beneficial effects of early strict glycemic control on microvascular complications and also on DAN: although CAN prevalence increased in both groups, the former intensive insulin treatment group continued to have a significantly lower decline in CAN through 13 or 14 years of EDIC follow-up. These long-term beneficial effects of early intensive glucose control have been called "metabolic memory" $(14,30,33,45,80-83)$. A 3 year prospective trial, by the use of PET cardiac imaging, has shown a similar beneficial effect of good glycemic control (defined by HbA1c $<8 \%$ ) on autonomic function (84).

The EURODIAB IDDM complication study and the EURODIAB Prospective study indicated that, apart from glycemic control, the incidence of DAN in patients with T2DM may be associated with potentially modifiable cardiovascular risk factors including a raised triglyceride level, body-mass index, smoking, and hypertension. This finding may be important for the development of risk reduction strategies $(67,85)$.

In T2DM, intensive glycemic control seems to be less effective in prevention of autonomic function deterioration $(14,33)$. During the VA Cooperative Study, no difference in the prevalence of autonomic neuropathy derived by the use of intensive insulin therapy and strict glycemic control in patients with T2DM (86). Three large studies (VADT, ACCOR, and ADVANCE) have reported that intensive glycemic control does not reduce all-cause mortality while increases hypoglycemic episode frequency (87-89).

The best results on prevention of autonomic dysfunction in patients with T2DM seem to be derived by multifactorial strategy treatment and lifestyle modification. Steno-2 study showed that a multifactorial cardiovascular risk intervention based on behavioral therapy (diet, smoking cessation, and physical exercise) and pharmacological intervention (to control hypertension, dyslipidemia, and hyperglicemia) retards development and progression of CAN in patients with T2DM and microalbuminuria (90). In the Diabetes Prevention Program (DPP) lifestyle modification, aimed to lose weight and physical activity, improved autonomic function indices (HR variation and QT indexes) more than metformin or placebo (91). A review published in 2007, has shown the improvement on autonomic function obtained from weight loss in individuals with diabetes and obesity (92). On the other hand, moderate endurance and aerobic exercise seem to improve cardiac autonomic function independent of BMI, blood pressure, glycemic control, and diabetes duration in patient with T1DM and T2DM as shown in a recent review in Ref. (93).

\section{THERAPY}

Once DAN becomes clinically evident, there is no treatment, which can effectively stop or reverse it. The most recent studies confirmed the efficacy of intensive insulin therapy in slowing the progression of both diabetic peripheral neuropathy (94) and DAN (95). This goal is obtained in T1DM by increasing the frequency of daily injections or by using a pump for continuous subcutaneous insulin infusion. In T2DM, several antihyperglycemic drugs, like sulfonylureas, GLP-1 agonists, thiazolidinediones, have shown beneficial effects in diabetes complications (51). In contrast, metformin seems to worsen neuropathic damage because of its effect on vitamin B12 (96). In particular, in the past years, attention has been paid to CAN outcomes. A number of treatments have been shown to target and contrast the pathogenetic pathways of CAN or to improve its symptoms. The efficacy of antioxidants like $\alpha$-lipoic acid or vitamin E in increasing HRV is controversial (14). Aldose reductase inhibitors (ARIs) studies have shown disappointing results because of the poor effects and the induction of adverse events like hepatic and renal toxicity. Recent experimental studies on ARIs look promising but they need to be validated (51, 97). The use of agents inhibiting peroxynitrite formation (FP15 and FeTMPS) has recently been examined in diabetic rats with positive outcomes (8).

Furthermore, C-peptide has shown beneficial effects on HRV in T1DM patients as it enhanced endoneurial blood flow, $\mathrm{Na}^{+} / \mathrm{K}^{+}$ pump activity, and neurotrophic factors release (97). Similarly, HRV may be treated with antihypertensive drugs (ACE inhibitors, angiotensin receptor blockers, cardioselective $\beta$-blockers, digoxin, and verapamil) (8).

Symptomatic orthostatic hypotension therapy has been extensively investigated. When lifestyle, behavioral measures, and physical countermanoeuvres are no longer effective, pharmacological intervention should be considered. Although only midodrine, an $\alpha 1$-adrenergic agonist, has been approved by the Food and Drug Administration for the therapy of orthostatic hypotension, $\alpha-2$ antagonists (clonidine), mineralocorticoids (9- $\alpha$-fluorohydrocortisone), non-selective $\beta$-blockers, somatostatin and its analogs (octreotide), erythropoietin, desmopressin acetate, cholinesterase inhibitor (pyridostigmine bromide), caffeine, and acarbose have been found to ameliorate symptoms through different mechanisms, albeit with limited effectiveness $(12,14)$.

Inhibitors of specific antioxidant pathways, especially NF-kB and Nfr-2, mitochondria targeted antioxidants as well as enhancers of mitochondrial functions have been suggested as future strategies against DAN (50). Finally, new possibilities have been opened by stem cells and gene therapy (32). 


\section{CONCLUSION}

In conclusion, DAN is a particular aspect of diabetic neuropathy, which leads to multisystemic impairment in both T1DM and T2DM patients. Cardiac system is the most seriously involved.

The pathogenesis of DAN has yet to be clarified but metabolic, genetic, and hormonal factors have been reported. The final common effect seems to be hyperglycemia resulting in oxidative stress and inflammation.

As nowadays no therapy is able to effectively reverse this process, prevention with strict glycemic control, multifactorial intervention, and lifestyle modification remains essential.

\section{REFERENCES}

1. Said G. Diabetic neuropathy. Handb Clin Neurol (2013) 115:579-89. doi:10. 1016/B978-0-444-52902-2.00033-3

2. Pasnoor M, Dimachkie MM, Kluding P, Barohn RJ. Diabetic neuropathy part 1: overview and symmetric phenotypes. Neurol Clin (2013) 31:425-45. doi:10.1016/j.ncl.2013.02.004

3. Boulton AJ, Gries FA, e Jervell JA. Guidelines for diagnosis and outpatient management of diabetic peripheral neuropathy. European association for the study of diabetes, neurodiab. Diabetes Metab (1998) 15(6):508-14.

4. Boulton AJ, Vinik AI, Arezzo JC, Bril V, Feldman EL, Freeman R, et al. Diabetic neuropathies: a statement by the American diabetes association. Diabetes Care (2005) 28:956-62. doi:10.2337/diacare.28.4.956

5. Tesfaye S, Boulton AJ, Dyck PJ, Freeman R, Horowitz M, Kempler P, et al. Diabetic neuropathies: update on definitions, diagnostic criteria, estimation of severity, and treatments. Diabetes Care (2010) 33:2285-93. doi:10.2337/dc10-1303

6. Trotta D, Verrotti A, Salladini C, Chiarelli F. Diabetic neuropathy in children and adolescents. Pediatr Diabetes (2004) 5(1):44-57. doi:10.1111/j.1399-543X. 2004.00041.x

7. Vinik AI, Maser RE, Mitchell BD, Freeman R. Diabetic autonomic neuropathy. Diabetes Care (2003) 26(5):1553-79. doi:10.2337/diacare.26.5.1553

8. Vinik AI, Maser RE, Ziegler D. Autonomic imbalance: prophet of doom or scope for hope? Diabet Med (2011) 28:643-51. doi:10.1111/j.1464-5491.2010. 03184.x

9. Pfeifer MA, Weinberg CR, Cook DL, Reenan A, Halter JB, Ensinck JW, et al. Autonomic neural dysfunction in recently diagnosed diabetic subjects. Diabetes Care (1984) 7:447-53. doi:10.2337/diacare.7.5.447

10. Said G, Bigo A, Améri A, Gayno JP, Elgrably F, Chanson P, et al. Uncommon early-onset neuropathy in diabetic patients. J Neurol (1998) 245:61-8. doi:10.1007/s004150050179

11. Ewing DJ, Martyn CN, Young RJ, Clarke BF. The value of cardiovascular autonomic function tests: 10 years experience in diabetes. Diabetes Care (1985) 8:491-8. doi:10.2337/diacare.8.5.491

12. Pop-Busui R. Cardiac autonomic neuropathy in diabetes: a clinical perspective. Diabetes Care (2010) 33:434-41. doi:10.2337/dc09-1294

13. Boysen A, Lewin MAG, Hecker W, Leichter HE. Autonomic function testing in children. Pediatr Diabetes (2007) 8:261-4. doi:10.1111/j.1399-5448.2007. 00254.x

14. Dimitropoulos G, Tahrani AA, Stevens MJ. Cardiac autonomic neuropathy in patients with diabetes mellitus. World J Diabetes (2014) 5:17-39. doi:10.4239/ wjd.v5.i1.17

15. Krause M, Rüdiger H, Bald M, Näke A, Paditz E. Autonomic blood pressure control in children and adolescents with type 1 diabetes mellitus. Pediatr Diabetes (2009) 10:255-63. doi:10.1111/j.1399-5448.2008.00447.x

16. Tang ZH, Zeng F, Li Z, Zhou L. Association and predictive value analysis for resting heart rate and diabetes mellitus on cardiovascular autonomic neuropathy in general population. J Diabetes Res (2014) 2014:215473. doi:10.1155/2014/ 215473

17. Pavy-Le Traon A, Fontaine S, Tap G, Guidolin B, Senard JM, Hanaire H. Cardiovascular autonomic neuropathy and other complications in type 1 diabetes. Clin Auton Res (2010) 20:153-60. doi:10.1007/s10286-010-0062-x

18. Antonelli Incalzi R, Fuso L, Pitocco D, Basso S, Trové A, Longobardi A, et al. Decline of neuroadrenergic bronchial innervation and respiratory function in type 1 diabetes mellitus: a longitudinal study. Diabetes Metab Res Rev (2007) 23:311-6. doi:10.1002/dmrr.688
19. Tantucci C, Scionti L, Bottini P, Dottorini ML, Puxeddu E, Casucci G, et al. Influence of autonomic neuropathy of different severities on the hypercapnic drive to breathing in diabetic patients. Chest (1997) 112:145-53. doi:10.1378/chest. 112.1 .145

20. Ludka O, Konecny T, Somers V. Sleep apnea, cardiac arrhythmias, and sudden death. Tex Heart Inst J (2011) 38:340-3.

21. Fujihara K, Kodama S, Horikawa C, Yoshizawa S, Sugawara A, Hirasawa R, et al. The relationship between diabetic neuropathy and sleep apnea syndrome: a meta-analysis. Sleep Disord (2013) 2013:150371. doi:10.1155/2013/150371

22. Chandrasekharan B, Srinivasan S. Diabetes and the enteric nervous system. Neurogastroenterol Motil (2007) 19:951-60. doi:10.1111/j.1365-2982.2007.01023.x

23. Chang J, Rayner CK, Jones KL, Horowitz M. Diabetic gastroparesis-backwards and forwards. J Gastroenterol Hepatol (2011) 26(Suppl 1):46-57. doi:10.1111/j. 1440-1746.2010.06573.x

24. Rutherford D, Collier A. Sexual dysfunction in women with diabetes mellitus. Gynecol Endocrinol (2005) 21:189-92. doi:10.1080/09513590400021110

25. Enzlin P, Mathieu C, Vanderschueren D, Demyttenaere K. Diabetes mellitus and female sexuality: a review of 25 years' research. Diabet Med (1998) 15:809-15. doi:10.1002/(SICI) 1096-9136(199810)15:10<809::AID-DIA689>3.0.CO;2-Z

26. Thorve VS, Kshirsagar AD, Vyawahare NS, Joshi VS, Ingale KG, Mohite RJ. Diabetes-induced erectile dysfunction: epidemiology, pathophysiology and management. J Diabetes Complications (2011) 25:129-36. doi:10.1016/j. jdiacomp.2010.03.003

27. Tang M, Donaghue KC, Cho YH, Craig ME. Autonomic neuropathy in young people with type 1 diabetes: a systematic review. Pediatr Diabetes (2013) 14:239-48. doi:10.1111/pedi.12039

28. Tentolouris N, Marinou K, Kokotis P, Karanti A, Diakoumopoulou E, Katsilambros N. Sudomotor dysfunction is associated with foot ulceration in diabetes. Diabet Med (2009) 26:302-5. doi:10.1111/j.1464-5491.2009.02677.x

29. Vinik AI, Nevoret ML, Casellini C, Parson H. Diabetic neuropathy. Endocrinol Metab Clin North Am (2013) 42:747-87. doi:10.1016/j.ecl.2013.06.001

30. Vinik AI, Erbas T. Diabetic autonomic neuropathy. Handb Clin Neurol (2013) 117:279-94. doi:10.1016/B978-0-444-53491-0.00022-5

31. Spallone V, Ziegler D, Freeman R, Bernardi L, Frontoni S, Pop-Busui R, et al. On behalf of the Toronto consensus panel on diabetic neuropathy. Cardiovascular autonomic neuropathy in diabetes: clinical impact, assessment, diagnosis, and management. Diabetes Metab Res Rev (2011) 27:639-53. doi:10.1002/dmrr.1239

32. Verrotti A, Loiacono G, Mohn A, Chiarelli F. New insights in diabetic autonomic neuropathy in children and adolescents. Eur J Endocrinol (2009) 161:811-8. doi:10.1530/EJE-09-0710

33. Karayannis G, Giamouzis G, Cokkinos DV, Skoularigis J, Triposkiadis F. Diabetic cardiovascular autonomic neuropathy: clinical implications. Expert Rev Cardiovasc Ther (2012) 10:747-65. doi:10.1586/erc.12.53

34. Maser RE, Mitchell BD, Vinik AI, Freeman R. The association between cardiovascular autonomic neuropathy and mortality in individuals with diabetes: a metaanalysis. Diabetes Care (2003) 26:1895-901. doi:10.2337/diacare.26.6.1895

35. Neil HA, Thompson AV, John S, McCarthy ST, Mann JI. Diabetic autonomic neuropathy: the prevalence of impaired heart rate variability in a geographically define population. Diabet Med (1989) 6:20-4. doi:10.1111/j.1464-5491.1989. tb01133.x

36. Ziegler D, Gries FA, Spüler M, Lessmann F. The epidemiology of diabetic neuropathy. diabetic cardiovascular autonomic neuropathy multicenter study group. J Diabetes Complications (1992) 6:49-57. doi:10.1016/1056-8727(92) 90049-Q

37. O'Brien IA, O'Hare JP, Lewin IG, Corrall RJ. The prevalence of autonomic neuropathy in insulin-dependent diabetes mellitus: a controlled study based on heart rate variability. Q J Med (1986) 61:957-67.

38. Verrotti A, Chiarelli F, Blasetti A, Morgese G. Autonomic neuropathy in diabetic children. J Paediatr Child Health (1995) 31:545-8. doi:10.1111/j.14401754.1995.tb00881.x

39. Solders G, Thalme B, Aguirre-Aquino M, Brandt L, Berg U, Persson A. Nerve conduction and autonomic nerve function in diabetic children. A 10-year follow-up study. Acta Paediatr (1997) 86:361-6. doi:10.1111/j.1651-2227.1997.tb09023.x

40. Karavanaki K, Baum JD. Coexistence of impaired indices of autonomic neuropathy and diabetic nephropathy in a cohort of children with type 1 diabetes mellitus. JPediatr Endocrinol Metab (2003) 16:79-90. doi:10.1515/JPEM.2003.16.1.79

41. The Diabetes Control and Complications Trial Research Group. The effect of intensive diabetes therapy on measures of autonomic nervous system function 
in the diabetes control and complications trial (DCCT). Diabetologia (1998) 41:416-23. doi:10.1007/s001250050924

42. Ziegler D, Gries FA, Mühlen H, Rathmann W, Spüler M, Lessmann F. Prevalence and clinical correlates of cardiovascular autonomic and peripheral diabetic neuropathy in patients attending diabetes centers. The Diacan Multicenter Study Group. Diabete Metab (1993) 19:143-51.

43. Valensi P, Pariès J, Attali JR. French group for research and study of diabetic neuropathy. Cardiac autonomic neuropathy in diabetic patients: influence of diabetes duration, obesity, and microangiopathic complications - the French multicenter study. Metabolism (2003) 52:815-20. doi:10.1016/S0026-0495(03) 00095-7

44. Low PA, Benrud-Larson LM, Sletten DM, Opfer-Gehrking TL, Weigand SD, O'Brien PC, et al. Autonomic symptoms and diabetic neuropathy: a populationbased study. Diabetes Care (2004) 27:2942-7. doi:10.2337/diacare.27.12.2942

45. Pop-Busui R, Low PA, Waberski BH, Martin CL, Albers JW, Feldman EL, et al. Effects of prior intensive insulin therapy on cardiac autonomic nervous system function in type 1 diabetes mellitus: the diabetes control and complications trial/epidemiology of diabetes interventions and complications study (DCCT/EDIC). Circulation (2009) 119:2886-93. doi:10.1161/ CIRCULATIONAHA.108.837369

46. Vinik AI, Freeman R, Erbas T. Diabetic autonomic neuropathy. Semin Neurol (2003) 23:365-72. doi:10.1055/s-2004-817720

47. de M Bandeira S, da Fonseca LJ, da S Guedes G, Rabelo LA, Goulart MO. Vasconcelos SM. Oxidative stress as an underlying contributor in the development of chronic complications in diabetes mellitus. Int J Mol Sci (2013) 14:3265-84. doi:10.3390/ijms14023265

48. Hoeldtke RD, Bryner KD, VanDyke K. Oxidative stress and autonomic nerve function in early type 1 diabetes. Clin Auton Res (2011) 21:19-28. doi:10.1007/ s10286-010-0084-4

49. Ziegler D, Buchholz S, Sohr C, Nourooz-Zadeh J, Roden M. Oxidative stress predicts progression of peripheral and cardiac autonomic nerve dysfunction over 6 years in diabetic patients. Acta Diabetol (2014). doi:10.1007/s00592-014-0601-3

50. Sandireddy R, Yerra VG, Areti A, Komirishetty P, Kumar A. Neuroinflammation and oxidative stress in diabetic neuropathy: futuristic strategies based on these targets. Int J Endocrinol (2014) 2014:674987. doi:10.1155/2014/674987

51. Forbes JM, Cooper ME. Mechanisms of diabetic complications. Physiol Rev (2013) 93:137-88. doi:10.1152/physrev.00045.2011

52. Takuma K, Fang F, Zhang W, Yan S, Fukuzaki E, Du H, et al. RAGE-mediated signaling contributes to intraneuronal transport of amyloid-beta and neuronal dysfunction. Proc Natl Acad Sci U S A (2009) 106:20021-6. doi:10.1073/pnas. 0905686106

53. Vinik AI. The conductor of the autonomic orchestra. Front Endocrinol (2012) 3:71. doi: $10.3389 /$ fendo.2012.00071

54. Dasu MR, Ramirez S, Isseroff RR. Toll-like receptors and diabetes: a therapeutic perspective. Clin Sci (2012) 122:203-14. doi:10.1042/CS20110357

55. Theilade S, Lyngbaek S, Hansen TW, Eugen-Olsen J, Fenger M, Rossing P, et al. Soluble urokinase plasminogen activator receptor levels are elevated and associated with complications in patients with type 1 diabetes. J Intern Med (2014). doi:10.1111/joim. 12269

56. Cameron NE, Dines KC, Cotter MA. The potential contribution of endothelin1 to neurovascular abnormalities in streptozotocin-diabetic rats. Diabetologia (1994) 37:1209-15. doi:10.1007/BF00399794

57. März P, Cheng JG, Gadient RA, Patterson PH, Stoyan T, Otten U, et al. Sympathetic neurons can produce and respond to interleukin 6. Proc Natl Acad Sci U S A (1998) 95:3251-6. doi:10.1073/pnas.95.6.3251

58. Pradhan AD, Manson JE, Rifai N, Buring JE, Ridker PM. C-reactive protein, interleukin 6, and risk of developing type 2 diabetes mellitus. JAMA (2001) 286:327-34. doi:10.1001/jama.286.3.327

59. Pepys MB, Hirschfield GM, Tennent GA, Gallimore JR, Kahan MC, Bellotti V, et al. Targeting C-reactive protein for the treatment of cardiovascular disease. Nature (2006) 440:1217-21. doi:10.1038/nature04672

60. Conti G, Scarpini E, Baron P, Livraghi S, Tiriticco M, Bianchi R, et al. Macrophage infiltration and death in the nerve during the early phases of experimental diabetic neuropathy: a process concomitant with endoneurial induction of ILlbeta and p75NTR. J Neurol Sci (2002) 195:35-40. doi:10.1016/S0022-510X(01) 00684-0

61. Navarro-González JF, Mora-Fernández C. The role of inflammatory cytokines in diabetic nephropathy. J Am Soc Nephrol (2008) 19:433-42. doi:10.1681/ASN. 2007091048
62. Lieb DC, Parson HK, Mamikunian G, Vinik AI. Cardiac autonomic imbalance in newly diagnosed and established diabetes is associated with markers of adipose tissue inflammation. Exp Diabetes Res (2012) 2012:878760. doi:10.1155/2012/878760

63. Ejskjaer N, Arif S, Dodds W, Zanone MM, Vergani D, Watkins PJ, et al. Prevalence of autoantibodies to autonomic nervous tissue structures in Type 1 diabetes mellitus. Diabet Med (1999) 16:544-9. doi:10.1046/j.1464-5491.1999.00092.x

64. Muhr D, Mollenhauer U, Ziegler AG, Haslbeck M, Standl E, Schnell O. Autoantibodies to sympathetic ganglia, GAD, or tyrosine phosphatase in long-term IDDM with and without ECG-based cardiac autonomic neuropathy. Diabetes Care (1997) 20:1009-12. doi:10.2337/diacare.20.6.1009

65. Granberg V, Ejskjaer N, Peakman M, Sundkvist G. Autoantibodies to autonomic nerves associated with cardiac and peripheral autonomic neuropathy. Diabetes Care (2005) 28:1959-64. doi:10.2337/diacare.28.8.1959

66. Skärstrand H, Dahlin LB, Lernmark A, Vaziri-Sani F. Neuropeptide Y autoantibodies in patients with long-term type 1 and type 2 diabetes and neuropathy. J Diabetes Complications (2013) 27:609-17. doi:10.1016/j.jdiacomp.2013. 06.007

67. Kempler P, Tesfaye S, Chaturvedi N, Stevens LK, Webb DJ, Eaton S, et al. Autonomic neuropathy is associated with increased cardiovascular risk factors: the EURODIAB IDDM complications study. Diabet Med (2002) 19:900-9. doi:10.1046/j.1464-5491.2002.00821.x

68. Nasr N, Czosnyka M, Arevalo F, Hanaire H, Guidolin B, Larrue V. Autonomic neuropathy is associated with impairment of dynamic cerebral autoregulation in type 1 diabetes. Auton Neurosci (2011) 160:59-63. doi:10.1016/j.autneu.2010. 10.001

69. Kasznicki J, Kosmalski M, Sliwinska A, Mrowicka M, Stanczyk M, Majsterek I, et al. Evaluation of oxidative stress markers in pathogenesis of diabetic neuropathy. Mol Biol Rep (2012) 39:8669-78. doi:10.1007/s11033-012-1722-9

70. Schmidt RE, Dorsey DA, Beaudet LN, Plurad SB, Parvin CA, Ohara S. Effect of IGF-I and neurotrophin-3 on gracile neuroaxonal dystrophy in diabetic and aging rats. Brain Res (2000) 876:88-94. doi:10.1016/S0006-8993(00)02602-0

71. Dasu MR, Jialal I. Effect of IGF-I and neurotrophin-3 on gracile neuroaxonal dystrophy in diabetic and aging rats. Am J Physiol Endocrinol Metab (2011) 300:E145-54. doi:10.1152/ajpendo.00490.2010

72. Goncalves AC, Tank J, Diedrich A, Hilzendeger A, Plehm R, Bader M. Diabetic hypertensive leptin receptor-deficient $\mathrm{db} / \mathrm{db}$ mice develop cardioregulatory autonomic dysfunction. Hypertension (2009) 53:387-92. doi:10.1161/ HYPERTENSIONAHA.108.124776

73. Ekberg K, Brismar T, Johansson BL, Lindström P, Juntti-Berggren L, Norrby A, et al. C-Peptide replacement therapy and sensory nerve function in type 1 diabetic neuropathy. Diabetes Care (2007) 30:71-6. doi:10.2337/dc06-1274

74. Pop-Busui R. What do we know and we do not know about cardiovascular autonomic neuropathy in diabetes. J Cardiovasc Transl Res (2012) 5:463-78. doi:10.1007/s12265-012-9367-6

75. Riihimaa PH, Suominen K, Tolonen U, Jäntti V, Knip M, Tapanainen P. Peripheral nerve function is increasingly impaired during puberty in adolescents with type 1 diabetes. Diabetes Care (2001) 24:1087-92. doi:10.2337/diacare.24.6.1087

76. Acerini CL, Williams RM, Dunger DB. Metabolic impact of puberty on the course of type 1 diabetes. Diabetes Metab (2001) 27:S19-25.

77. Fleischer J. Diabetic autonomic imbalance and glycemic variability. J Diabetes Sci Technol (2012) 6:1207-15. doi:10.1177/193229681200600526

78. The Diabetes Control and Complications Trial Research Group. The effect of intensive treatment of diabetes on the development and progression of longterm complications in insulin-dependent diabetes mellitus. N Engl J Med (1993) 329:977-86. doi:10.1056/NEJM199309303291401

79. Albers JW, Kenny DJ, Brown M, Greene D, Cleary PA, Lachin JM, et al. Effect of intensive diabetes treatment on nerve conduction in the diabetes control and complications trial. Ann Neurol (1995) 38:869-80.

80. Martin CL, Albers JW, Pop-Busui R. DCCT/EDIC research group. Neuropathy and related findings in the diabetes control and complications trial/epidemiology of diabetes interventions and complications study. Diabetes Care (2014) 37:31-8. doi:10.2337/dc13-2114

81. Writing Team for the Diabetes Control and Complications Trial/Epidemiology of Diabetes Interventions and Complications Research Group. Effect of intensive therapy on the microvascular complications of type 1 diabetes mellitus. JAMA (2002) 287:2563-9. doi:10.1001/jama.287.19.2563

82. Writing Team for the Diabetes Control and Complications Trial/Epidemiology of Diabetes Interventions and Complications Research Group. Sustained effect 
of intensive treatment of type 1 diabetes mellitus on development and progression of diabetic nephropathy: the Epidemiology of Diabetes Interventions and Complications (EDIC) study. JAMA (2003) 290:2159-67. doi:10.1001/jama.290. 16.2159

83. LeRoith D, Fonseca V, Vinik A. Metabolic memory in diabetes - focus on insulin. Diabetes Metab Res Rev (2005) 21:85-90. doi:10.1002/dmrr.530

84. Stevens MJ, Raffel DM, Allman KC, Schwaiger M, Wieland DM. Regression and progression of cardiac sympathetic dysinnervation complicating diabetes: an assessment by C-11 hydroxyephedrine and positron emission tomography. Metabolism (1999) 48:92-101. doi:10.1016/S0026-0495(99)90016-1

85. Tesfaye S, Chaturvedi N, Eaton SE, Ward JD, Manes C, Ionescu-Tirgoviste C, et al. EURODIAB prospective complications study group. Vascular risk factors and diabetic neuropathy. N Engl J Med (2005) 352:341-50. doi:10.1056/ NEJMoa032782

86. Azad N, Emanuele NV, Abraira C, Henderson WG, Colwell J, Levin SR, et al. The effects of intensive glycemic control on neuropathy in the VA cooperative study on type II diabetes mellitus (VA CSDM). J Diabetes Complications (1999) 13:307-13. doi:10.1016/S1056-8727(99)00062-8

87. Duckworth W, Abraira C, Moritz T, Reda D, Emanuele N, Reaven PD, et al. VADT investigators. Glucose control and vascular complications in veterans with type 2 diabetes. N Engl J Med (2009) 360:129-39. doi:10.1056/ NEJMoa0808431

88. Gerstein HC, Miller ME, Byington RP, Goff DC Jr, Bigger JT, Buse JB, et al. Action to control cardiovascular risk in diabetes study group. Effects of intensive glucose lowering in type 2 diabetes. N Engl J Med (2008) 358:2545-59. doi:10.1056/NEJMoa0802743

89. Patel A, MacMahon S, Chalmers J, Neal B, Billot L, Woodward M, et al. Advance collaborative group. Intensive blood glucose control and vascular outcomes in patients with type 2 diabetes. N Engl J Med (2008) 358:2560-72. doi:10.1056/NEJMoa0802987

90. Gaede P, Vedel P, Larsen N, Jensen GV, Parving HH, Pedersen O. Multifactorial intervention and cardiovascular disease in patients with type 2 diabetes. $N$ Engl J Med (2003) 348:383-93. doi:10.1056/NEJMoa021778

91. Carnethon MR, Prineas RJ, Temprosa M, Zhang ZM, Uwaifo G, Molitch ME. The association among autonomic nervous system function, incident diabetes, and intervention arm in the diabetes prevention program. Diabetes prevention program research group. Diabetes Care (2006) 29:914-9. doi:10.2337/diacare. 29.04.06.dc05-1729
92. Maser RE, Lenhard MJ. An overview of the effect of weight loss on cardiovascular autonomic function. Curr Diabetes Rev (2007) 3:204-11. doi:10.2174/ 157339907781368931

93. Voulgari C, Pagoni S, Vinik A, Poirier P. Exercise improves cardiac autonomic function in obesity and diabetes. Metabolism (2013) 62:609-21. doi:10.1016/j. metabol.2012.09.005

94. Callaghan BC, Little AA, Feldman EL, Hughes RA. Enhanced glucose control for preventing and treating diabetic neuropathy. Cochrane Database Syst Rev (2012) 6:CD007543. doi:10.1002/14651858.CD007543.pub2

95. Lee SS, Han HS, Kim H. A 5-yr follow-up nerve conduction study for the detection of subclinical diabetic neuropathy in children with newly diagnosed insulin-dependent diabetes mellitus. Pediatr Diabetes (2010) 11:521-8. doi:10.1111/j.1399-5448.2009.00636.x

96. Wile DJ, Toth C. Association of metformin, elevated homocysteine, and methylmalonic acid levels and clinically worsened diabetic peripheral neuropathy. Diabetes Care (2010) 33:156-61. doi:10.2337/dc09-0606

97. Ekberg K, Johansson BL. Effect of C-peptide on diabetic neuropathy in patients with type 1 diabetes. Exp Diabetes Res (2008) 2008:457912. doi:10.1155/2008/ 457912

Conflict of Interest Statement: The authors declare that the research was conducted in the absence of any commercial or financial relationships that could be construed as a potential conflict of interest.

Received: 30 July 2014; accepted: 17 November 2014; published online: 01 December 2014.

Citation: Verrotti A, Prezioso G, Scattoni R and Chiarelli F (2014) Autonomic neuropathy in diabetes mellitus. Front. Endocrinol. 5:205. doi: 10.3389/fendo.2014.00205 This article was submitted to Diabetes, a section of the journal Frontiers in Endocrinology.

Copyright (C) 2014 Verrotti, Prezioso, Scattoni and Chiarelli. This is an open-access article distributed under the terms of the Creative Commons Attribution License (CC $B Y)$. The use, distribution or reproduction in other forums is permitted, provided the original author(s) or licensor are credited and that the original publication in this journal is cited, in accordance with accepted academic practice. No use, distribution or reproduction is permitted which does not comply with these terms. 